\title{
Floral-oil-producing Plantaginaceae species: geographical distribution, pollinator rewards and interactions with oil-collecting bees
}

\author{
Aline Cristina Martins ${ }^{1,3}$ \& Isabel Alves-dos-Santos ${ }^{2}$ \\ ${ }^{1}$ Pós-graduação em Entomologia, Faculdade de Filosofia, Ciências e Letras de Ribeirão Preto, \\ Universidade de São Paulo - USP, CEP 14040-901, Ribeirão Preto, SP, Brazil \\ ${ }^{2}$ Departamento de Ecologia, Instituto de Biociências, Universidade de São Paulo - USP, \\ CEP 05508-090, São Paulo, SP, Brazil \\ ${ }^{3}$ Corresponding author: Aline Cristina Martins, e-mail:aline_cmartins@yahoo.com.br
}

MARTINS, A.C. \& ALVES-DOS-SANTOS, I. Floral-oil-producing Plantaginaceae species: geographical distribution, pollinator rewards and interactions with oil-collecting bees. Biota Neotrop. 13(4): http://www. biotaneotropica.org.br/v13n4/en/abstract?article+bn01313042013

\begin{abstract}
Floral oils as reward to pollinators occur in eleven plant families and appeared at least 28 times in the evolutionary history of flowering plants. They are produced in epithelial or tricomatic glands and collected by oil bee visitors. The present paper focuses on floral-oil-producing species of Plantaginaceae, a Neotropical group namely Angelonia clade. This group comprises around 40 described species in the genera Angelonia, Basistemon, Monttea, Monopera and the oil-less Melosperma . We present a revision of all species of the Angelonia clade, their geographical distribution, resources offered to pollinators and records of flower visitors, especially oil-collecting bees. These plants rely only on oil-collecting species in the tribe Centridini and Tapinotaspidini for a successful pollination, being the interaction between both partners an especial case of bee/flower adaptation in Neotropical region. Some bee species depend only on the oil of Plantaginaceae flowers to survive, while others can collect on several floral oil sources. The pollinating bees explore the oil glands located in sacs using specialized hairs in the forelegs. With this study, we hope to inspire further research relating to this fascinating group of plants, in which most species are rare and occur in highly endangered habitats in South American open vegetation biomes. keywords: plant-insect interactions, oil-collecting bees, oil-flowers, Plantaginaceae, Apidae.
\end{abstract}

MARTINS, A.C. \& ALVES-DOS-SANTOS, I. As espécies produtoras de óleo floral da família Plantaginaceae: distribuição geográfica, recursos oferecidos e interações com abelhas coletoras de óleo. 13(4): http://www. biotaneotropica.org.br/v13n4/pt/abstract?article+bn01313042013

Resumo: Os óleos florais como recompensa a polinizadores estão presentes em onze famílias e surgiram ao menos 28 vezes na história evolutiva das plantas floríferas. Estes são produzidos em glândulas tricomáticas ou epiteliais e coletados por abelhas coletoras de óleo. O presente trabalho foi focado nas espécies produtoras de óleo floral de Plantaginaceae, um grupo neotropical conhecido como clado Angelonia. Este grupo compreende cerca de 40 espécies nos gêneros Angelonia, Basistemon, Monttea, Monopera e Melosperma, que não produz óleo floral. Nós apresentamos uma revisão de todas as espécies no clado Angelonia, sua distribuição geográfica, recursos oferecidos e registros de visitantes florais, especialmente abelhas coletoras de óleo. Estas plantas dependem das abelhas coletoras de óleo das tribos Centridini e Tapinotaspidini para uma polinização bem-sucedida, sendo a interação entre ambos os parceiros um caso especial de adaptação abelha/planta na Região Neotropical. Algumas espécies dependem somente do óleo coletado em espécies do clado Angelonia, enquanto outras também podem coletar em várias fontes de óleos florais. Essas abelhas exploram as glândulas de óleo localizadas em bolsas utilizando pelos especializados nas pernas anteriores. Com o presente trabalho esperamos inspirar estudos futuros com este fascinante grupo de plantas, que são em sua maioria espécies raras e que ocorrem nos altamente ameaçados biomas de vegetação aberta da América do Sul.

Palavras-chave: interações inseto-planta, abelhas coletoras de óleo, flores de óleo, Plantaginaceae, Apidae 


\section{Introduction}

The origin of floral oil production in angiosperms is polyphyletic as well as the oil-collecting behavior in bees (Renner \& Schaefer 2010). Specifically floral oil production evolved at least 28 times and was lost 36-38 times in the evolutionary history of flowering plants (Renner \& Schaefer 2010). Stefan Vogel (Univ. Vienna) first observed oil production glands on the corolla of Angelonia and Calceolaria (Vogel 1969). Further Vogel's investigations were compiled in extensive monographs, where he distinguished the oil-producing glands in two types: I. Trichomatic elaiophores - fields of hundreds to thousands of glandular trichomes (Cucurbitaceae, Iridaceae, Myrsinaceae (Lysimachia), part of Orchidaceae, Scrophulariaceae s.l., Solanaceae (Nierenbergia)); and II. Epithelial elaiophores - groupings of secretory epidermal cells recovered by a thin cuticle (Krameriaceae, Malpighiaceae and part of Orchidaceae) (Vogel 1974, 1986, 1990). Nowadays this floral reward is the third most common reward to specialized pollinators (Simpson \& Neff 1981).

Neotropical oil-producing species in Plantaginaceae and Calceolariaceae were until recent years classified in the traditional and polyphyletic family Scrophulariaceae (Olmstead et al. 2001). Scropulariacae sensu lato comprised also the African floral-oilproducing genera Anastrabe, Bowkeria and Ixianthes, which were re-classified in Stilbaceae, and Alonsoa, Colpias, Diascia and Hemimeris, which were maintained in Scrophulariaceae sensu stricto (Olmstead et al. 2001, Oxelman et al. 2005). Furthermore the Neotropical Andean genus Calceolaria, with around 200 species, (Molau 1988), was classified in the new family Calceolariaceae (Olmstead et al. 2001) while the remaining Neotropical oil genera were re-classified in the newly expanded Plantaginaceae (Albach et al. 2005).

Plantaginaceae is a widespread family that comprises about 90 genera and 1900 species mainly distributed in temperate regions. In general, it is difficult to distinguish from Scrophulariaceae sensu stricto and related families, all possessing large and zygomorphic flowers (Stevens 2012). On the other hand, the oil-producing species appeared only in the tribe Angeloniae, which comprises also the oil-less Ourisia, sister-group to Angelonia clade (Albach et al. 2005). The production of floral oils as a reward to pollinators in the Angelonia clade seems to be an ancestral condition, with losses in Basistemon, and origin of nectaries in Melosperma andicola and Monttea, which offers oil and nectar. (Simpson et al. 1990, Vogel \& Cocucci 1995, Sérsic \& Cocucci 1999, Tadey 2011). Moreover another Plantaginaceae, Mecardonia tenella was reported to attract males and females of the oil-collecting bee Lanthanomelissa betinae (Cappellari et al. 2009), but the purpose of the visit remains unknown. However the evidence of oil-production in M. tenella deserves further investigation, but since this genus is included in Gratiolae, which is sister-group to Angeloniae (Albach et al. 2005), it could represent an ancestral state of oil-production in Plantaginaceae (Cappellari et al. 2009).

In this paper, we compiled all species of the Angelonia clade, their geographical distribution, morphological traits related to pollination in oil flowers and oil-collecting visitors. We discuss the gaps in the available information and in pollination studies, and the information that would be required for a better understanding of the interaction of the flowers and their bee visitors.

\section{How the Data was Compiled}

Data on the taxonomy and geographical distribution of the plants were compiled from Barringer $(1981,1983,1985)$ and Souza \& Giulietti (2009). Taxonomic information for species occurring in Brazil was updated according to Souza \& Giulietti (2009) synonym proposal. Information about pollination and interactions with flower visitors was compiled from the literature using the website Web of Knowledge (http://www.webofknowledge.com/) and Google Scholar (http://scholar.google.com) by searching for the keywords: oil-bees, oil-flowers, Plantaginaceae, Neotropical, as well as the name of plant and bee genera involved in the described interactions (for example, Angelonia or Centris). The names of flower bee visitors were updated according to Moure et al. (2012). The resources offered to flower visitors were inferred through the morphological features of the flowers, as described in the literature (e.g. the presence of nectaries or elaiophores). Vegetation types for the localities where pollination studies were performed, when not described in the respective papers, were inferred by assembling the geographic coordinates of the study site with the WWF map of ecoregions (Olson \& Dinerstein 2002) in DIVA-GIS (Diva-Gis, 2011).

Morphological features for the oil producing species were compiled from the literature (Barringer 1981, 1983, 1985, Souza \& Giulietti 2009, Simpson et al. 1990, Sérsic \& Cocucci 1999). We consider here the most important features related to flower visitors, the presence of the developed calluses and size of oil sacs (Martins et al. 2013). Here is used the term proximal callus (Vogel \& Machado 1990), for the structure of Angelonia flowers named also as anterior callus (Vogel \& Machado 1990), horn (Barringer 1981) or appendix (Souza \& Giulietti 2009). The term "oil sac" was preferred to refer to the place where most of the glandular trichomes were located in the corolla of Plantaginaceae oil-flowers, instead of giba (Souza \& Giulietti 2009), pouch (Vogel \& Machado 1990) or spur, the common term used for the Scrophulariaceae s.l. flowers (Steiner \& Whitehead 1990).

For illustration and comparative purposes, three species in the clade were collected in the following localities in Brazil, with the respective coordinates: Angelonia eryostachis, Rio Preto State Park in São Gonçalo do Rio Preto (Minas Gerais) (18 $12^{\prime}$ S, $43^{\circ} 19^{\prime} \mathrm{W}$ ); Angelonia integerrima, Vila Velha State Park in Ponta Grossa (Paraná) ( $30^{\circ} 07^{\prime} \mathrm{S}, 51^{\circ} 14^{\prime} \mathrm{W}$ ); and Basistemon silvaticus, Porto Murtinho (Mato Grosso Sul) $\left(21^{\circ} 37^{\prime} \mathrm{S}, 57^{\circ} 49^{\prime} \mathrm{W}\right)$. The collected flowers were fixed in FAA (37\% formaldehyde, acetic acid and 50\% ethanol, 1:1:2). Those species were selected because they are relatively unknown in terms of morphology and interactions with pollinators and represent different morphological types within the Plantaginaceae oil-producing species. The localities for collecting were chosen according to the geographical distribution of the species (Souza \& Giulietti 2009), as well as accessibility.

Fresh flowers of $A$. integerrima were dissected tangentially or kept completely for photographs in different views. Several pictures of each view were captured with a camera coupled to a Leica Stereoscopic Microscope, and later assembled with Automontage Pro software. A. eryostachis and B. silvaticus flowers were dissected by cutting them tangentially, and one of each was illustrated using a camera lucida. The images were then treated in CorelDraw.

\section{Angelonia clade}

The clade Angelonia comprises the five genera Angelonia, Basistemon, Monttea, Monopera and Melosperma (Albach et al. 2005) (Figure 1). In fact, the phylogenetic position of Monopera within the Angelonia clade (Albach et al. 2005) is inferred by morphological similarities with Angelonia (Barringer 1983). Although records of the environments in which they occur are incomplete, the available data show that the species of this clade are more strongly associated with open and dry vegetation areas, such as the savannas, seasonally dry tropical forest and Chaco biomes in Neotropical Region. 

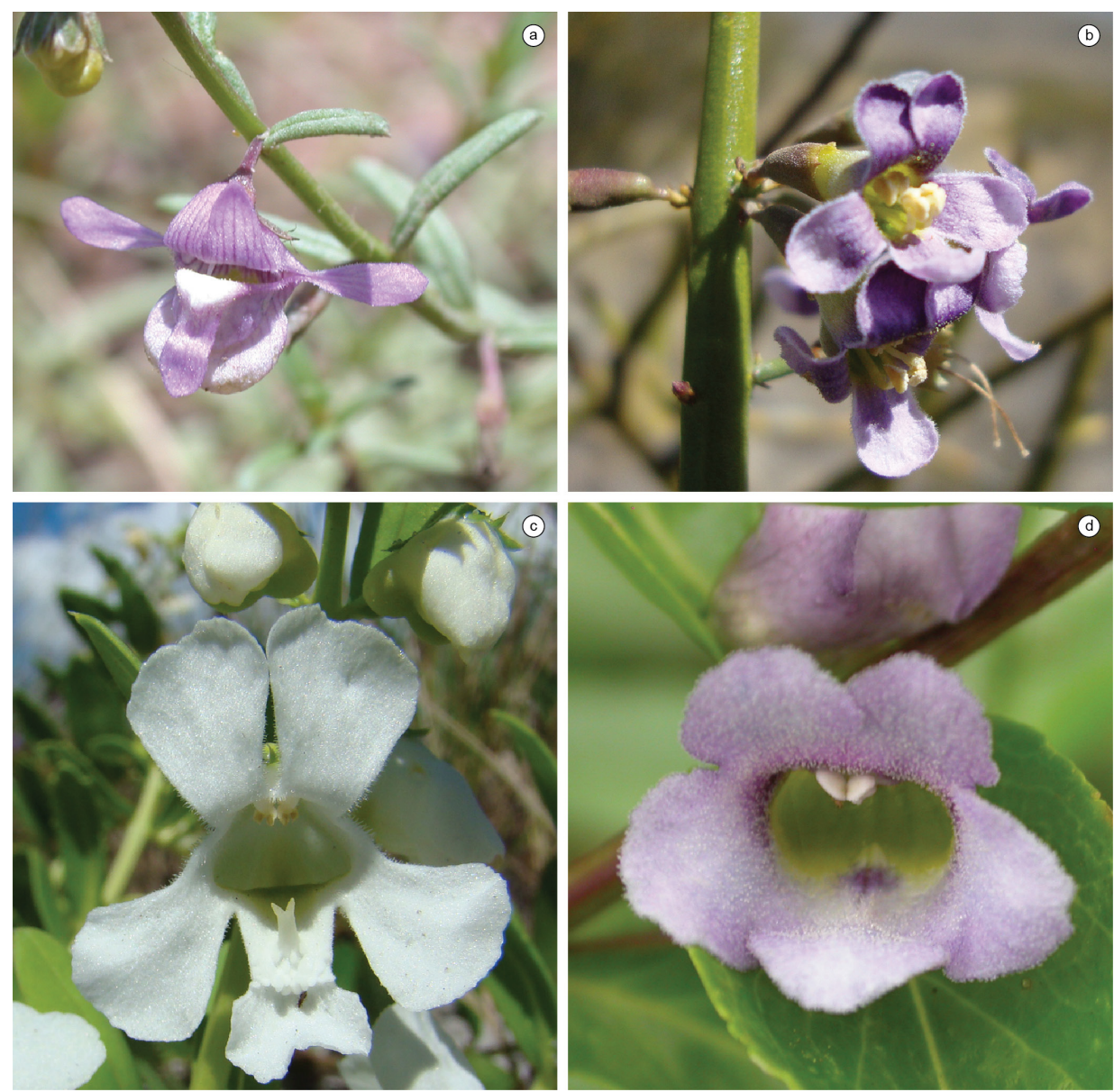

Figure 1. Floral-oil-offering species in Plantaginaceae. a. Monopera perennis, Porto Murtinho ( $21^{\circ} 34^{\prime} 21^{\prime \prime} \mathrm{S}$ e $\left.57^{\circ} 48^{\prime} 65^{\prime \prime} \mathrm{W}\right)$, Brazil (Photo by Gabriel A. R. Melo); b. Monttea aphylla, Villavicencio Natural Reserve, Argentina ( $\left.32^{\circ} 35^{\prime} 7^{\prime \prime} \mathrm{S}, 68^{\circ} 59^{\prime} 2^{\prime \prime} \mathrm{W}\right)$ (Photo by Mariana Taniguchi); c. Angelonia goyazensis, Rio Preto State Park, Brazil; d. Basistemon silvaticus, Porto Murtinho, Brazil.

The most widely distributed and diverse genus is Angelonia (Figure 2a), with around 30 species that occur from Mexico to Argentina (Barringer 1981, Souza \& Giulietti 2009) (Table 1). These numbers are possibly inaccurate, however, as this genus needs a taxonomic revision (VC Souza, personal communication). Many Angelonia species are endemic to Brazil (e.g. A. alternifolia, A. arguta), while some are distributed broadly in South and Central America, as A. angustifolia (Table 1). Angelonia species are herbs or shrubs and live in humid or flooded soil near rivers (Figure 2b). On the other hand, Monopera contains only two herbaceous species, M. perennis, occurring in Brazil (Mato Grosso do Sul) and Paraguay, and M. micrantha, occurring in seasonally dry tropical forest in northeastern Brazil (Souza \& Giulietti 2009). Records of Monopera are rare in both herbaria and literature: there are only 27 records in the database of Species Link (http://www.splink.org.br/).

Basistemon occurs in parts of Central Brazil and across the Andean countries Argentina, Bolivia, Colombia, Peru and Venezuela (Barringer 1985). Barringer (1985) consider eight species in this genus, however Souza \& Giulietti (2009) synonymized B. argutus, $B$. intermedius, $B$. klugii, and B. pulchellus in B. peruvianus due to the many characters in common and slightly differences that does not justify the separation. In addition, Basistemon species are rarely collected, and for most of these species, with the exception of $B$. silvaticus and $B$. spinosus, we known only the type specimens.

Monttea and Melosperma are sister-groups (Albach et al. 2005). Monttea present three species occurring in Argentina and Chile: $M$. aphylla, M. chilensis and M. schickendantzii, while Melosperma comprises only one species, $M$. andicola. The Monttea and Melosperma species occur only in arid regions of temperate South America, being the last one restricted to Andean regions (Sérsic \& Cocucci 1999).

\section{Morphology of Plantaginaceae Oil-Rewarding Flowers}

The floral-oil-producing Plantaginaceae vary in terms of habit and morphology, although some traits are common to all species, such as purple or white flowers, two pairs of stamens and trichomatic elaiophores located in one or two sacs (Table 2). The flowers are gamopetalous, forming a not-very-well-defined tube, which, in the majority of Angelonia species, possess five lobes and is similar to an open mouth (Figure 1c). The pair of oil sacs varies between species in size and shape, and holds the trichomatic elaiophores (Figure 3a,b) (Table 2), which bees explore with their forelegs (Vogel 1974). In Angelonia clade, both male and female reproductive organs are located in the superior part of the corolla entrance (Figures 4 and 5), and at least in Angelonia and Basistemon the development is protandrous, a mechanism to avoid self-pollination. The flowers of M. aphylla, is weakly self-compatible and minimally autogamous, as well as most of species studied by Vogel \& Machado (1991). The literature present data on the pollination biology of six species of Angelonia: A. salicariifolia (cited as A. hirta), A. campestris (cited as two species, A. bisaccata and A. hookeriana), A. pubescens, 
Martins, A.C. \& Alves-dos-Santos, I.

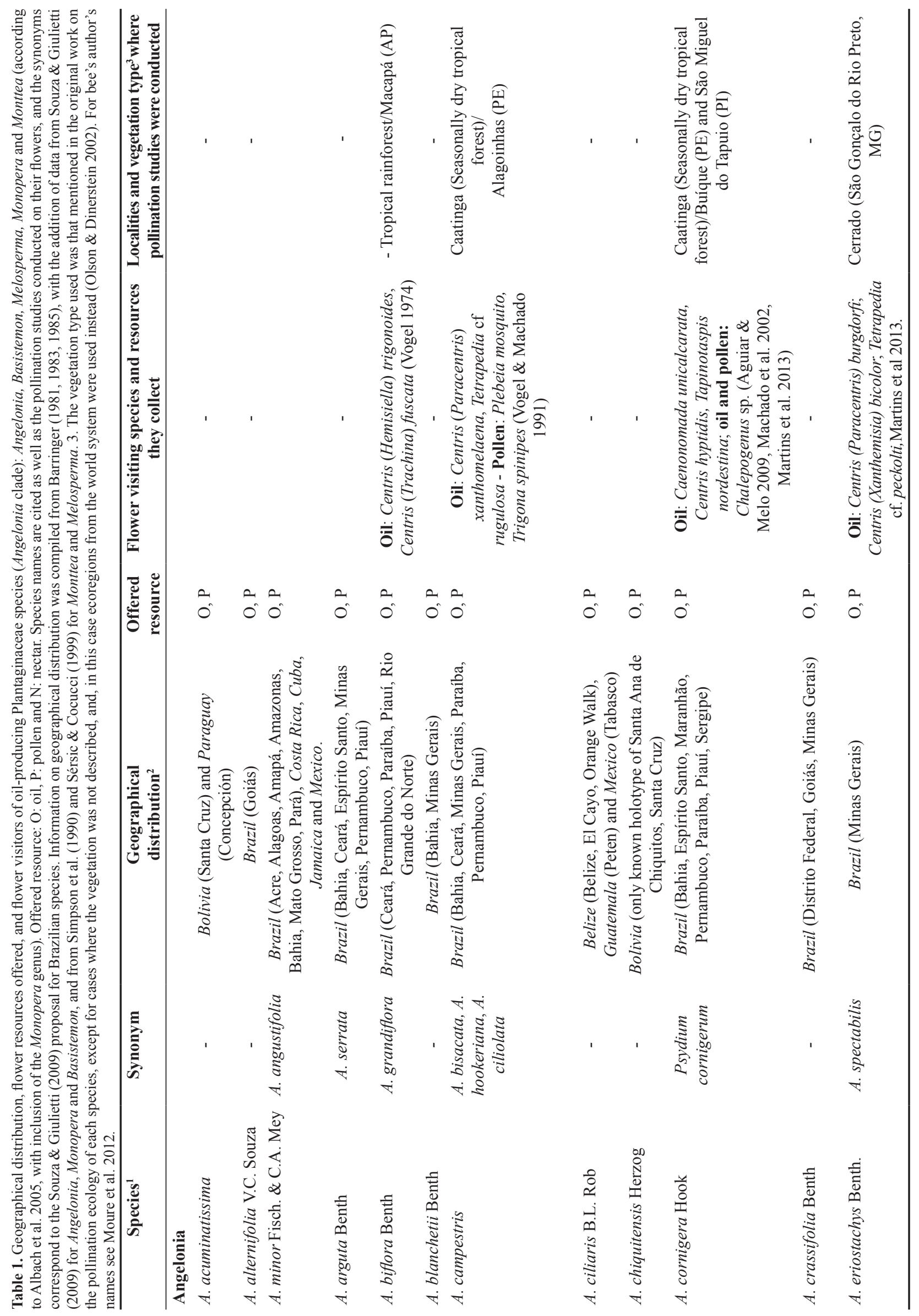




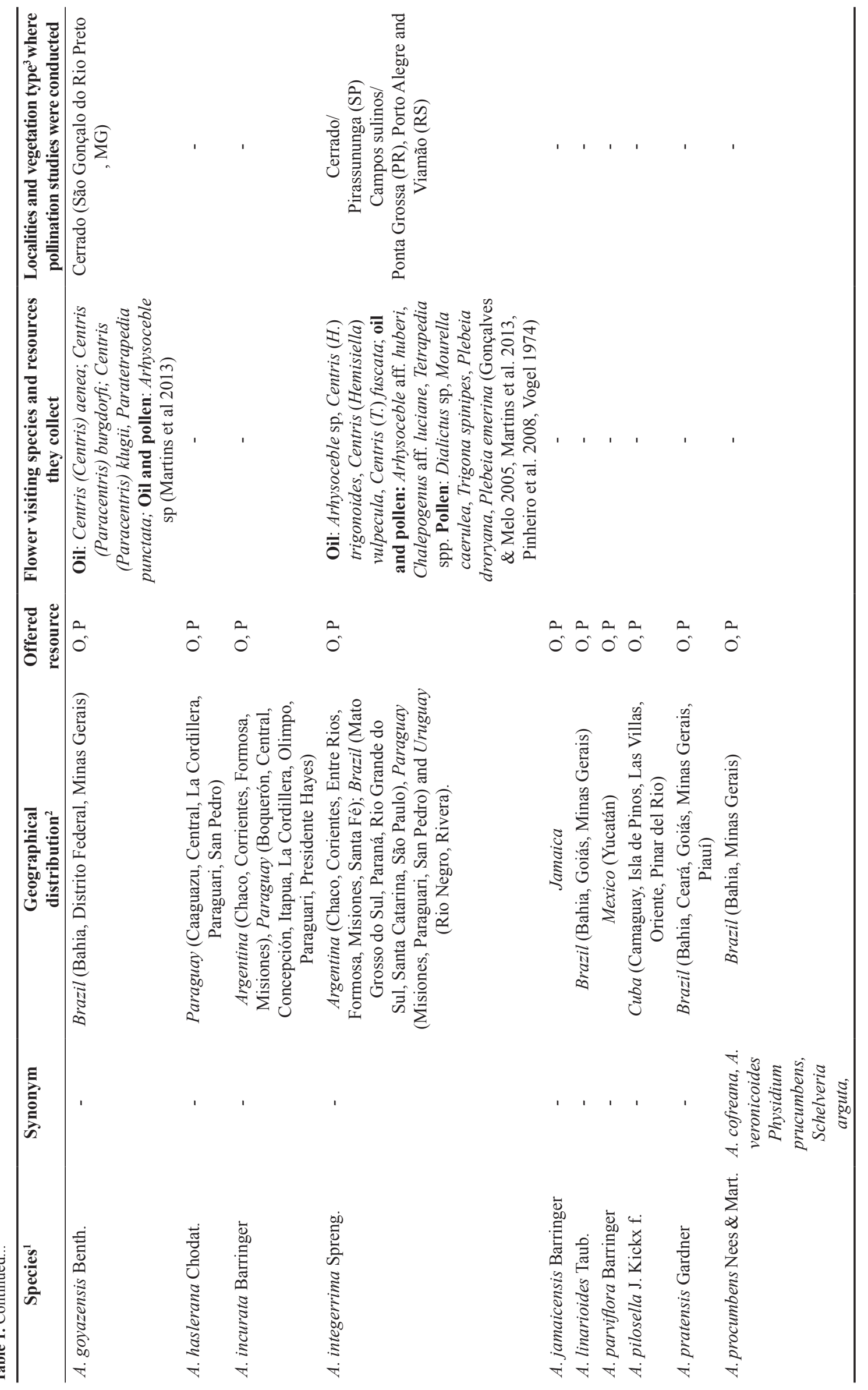




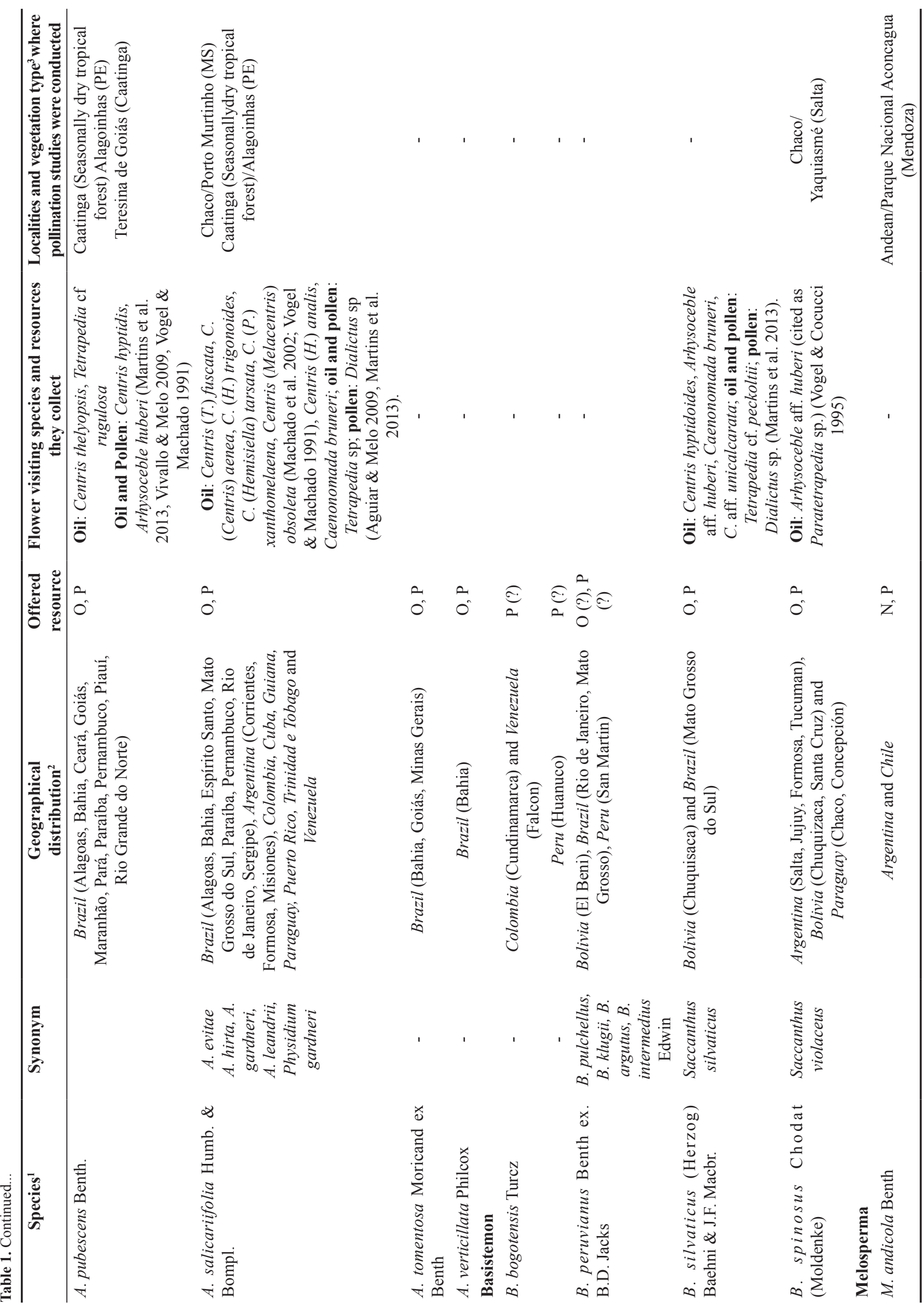




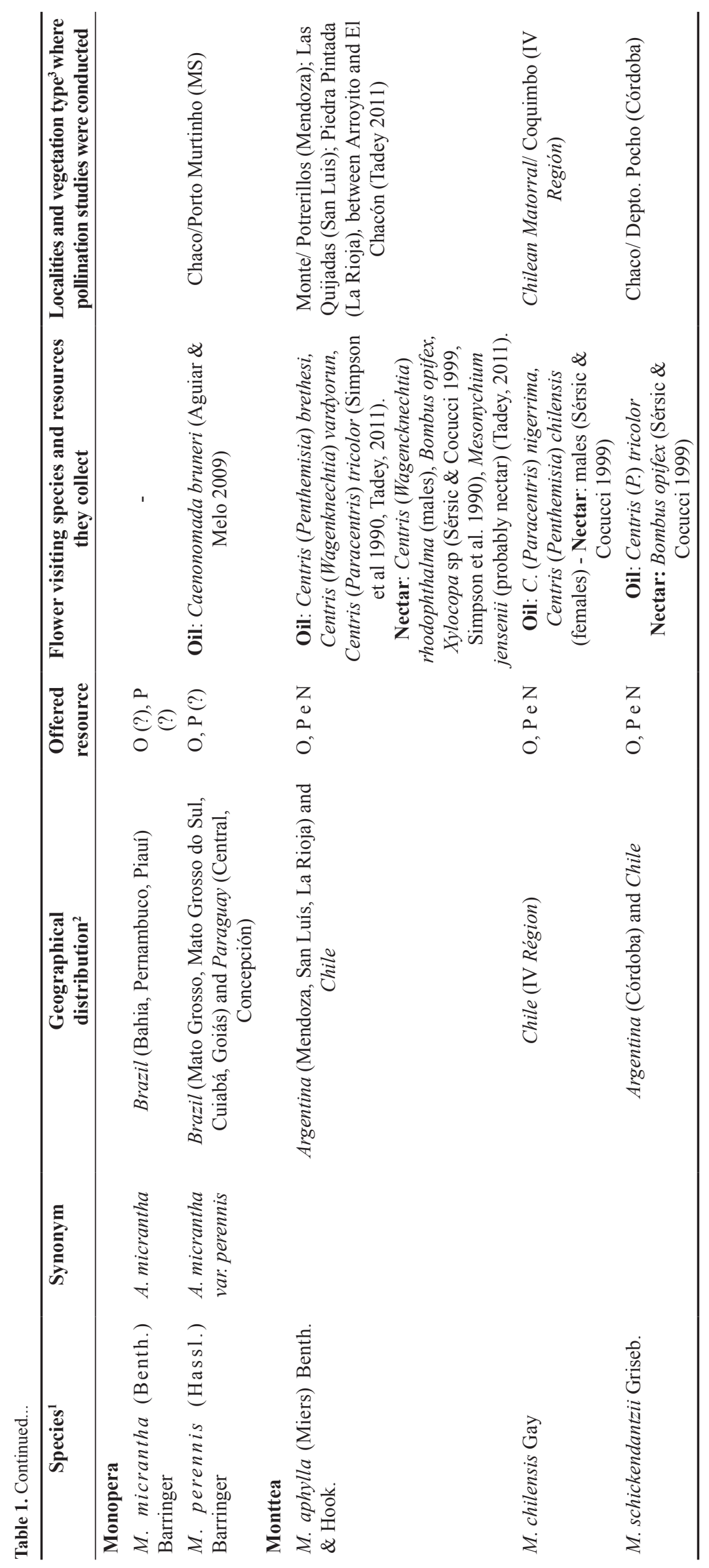


Table 2. Floral morphology of oil-offering Angelonia clade species, with focus on pollination related traits, compiled from Souza \& Giulietti (2009) for the species occurring in Brazil and complemented with information about the non-Brazilian species present in Barringer (1981) (Angelonia), (1985) (Basistemon) (1983), (Monopera), Simpson et al. (1990) (Monttea aphlla) and Sérsic \& Cocucci (1999) (Monttea and Melosperma).

\begin{tabular}{|c|c|c|c|c|}
\hline Species & Flower arrangement & Flower collor & Proximal callus & Oil sacs \\
\hline \multicolumn{5}{|l|}{ Angelonia } \\
\hline A. acuminatissima & terminal raceme & violet & bifid & prominent \\
\hline A. alternifolia & terminal raceme & purple & discrete or absent & rounded, discrete \\
\hline A. angustifolia & solitary & purple or lilac & bifid & rounded \\
\hline A. arguta & solitay, almost a raceme & purple & bifid & rounded \\
\hline A. biflora & solitaria & purple or blue & bifid & rounded, discrete \\
\hline A. blanchetii & solitay, almost a raceme & pink or purple & bifid & rounded \\
\hline A. campestris & solitary & violet or purple & discrete or absent & prominent \\
\hline A. ciliaris & terminal raceme & blue with purple dots & bifid & $?$ \\
\hline A. chiquitensis & terminal raceme & violet or blue & bifid & $?$ \\
\hline A. cornigera & solitary & purple or white & bituberculate & $\begin{array}{c}\text { prominent and laterally } \\
\text { expanded }\end{array}$ \\
\hline A. crassifolia & solitary & violet or purple & bifid & rounded \\
\hline A. eriostachys & terminal raceme & $\begin{array}{l}\text { lilac or purple, with } \\
\text { dark spots }\end{array}$ & discrete or absent & rounded, discrete \\
\hline A. goyazensis & terminal raceme & purple, lilac or white & bifid & prominent \\
\hline A. haslerana & 1-2 axyls of upper leaves & violet or rose & discrete or absent & discrete \\
\hline A. hirta & terminal raceme & $\begin{array}{l}\text { violet and white, with } \\
\text { brown spots }\end{array}$ & bifid & prominent \\
\hline A. incurata & terminal raceme & violet & bifid & $?$ \\
\hline A. integerrima & thyrse & $\begin{array}{l}\text { lilac or blue, with } \\
\text { purple spots }\end{array}$ & discrete or absent & prominent \\
\hline A. jamaicensis & raceme & violet & $?$ & $?$ \\
\hline A. linarioides & solitary & purple, lilac or white & bifid & $\begin{array}{l}\text { prominent, but almost } \\
\text { unisaccate }\end{array}$ \\
\hline A. parviflora & raceme & purple & bifid & $?$ \\
\hline A. pilosella & raceme & purple & bifid & $?$ \\
\hline A. pratensis & solitary & purple & bifid & prominent \\
\hline A. procumbens & solitary & $\begin{array}{c}\text { rose, white or pale } \\
\text { blue with spots lilac or } \\
\text { brown }\end{array}$ & long and linear & discrete \\
\hline A. pubescens & solitary & purple & $\begin{array}{c}\text { linear with globular } \\
\text { apex }\end{array}$ & $\begin{array}{l}\text { prominent and laterally } \\
\text { expanded }\end{array}$ \\
\hline A. salicariifolia & terminal raceme & $\begin{array}{l}\text { purple, blue, rose, lilac } \\
\text { and white }\end{array}$ & bifid & prominent \\
\hline A. tomentosa & terminal raceme & purple or blue & discrete or absent & rounded, discrete \\
\hline A. verticillata & terminal raceme & purple & discrete or absent & rounded, discrete \\
\hline \multicolumn{5}{|l|}{ Basistemon } \\
\hline B. bogotensis & axillary and sollitary & white & absent & discrete, glabrous \\
\hline B. peruvianus & axillary clusters & white & absent & $\begin{array}{l}\text { discrete, slightly glandular } \\
\text { pubescent }\end{array}$ \\
\hline B. silvaticus & solitary and axillary & purple or white & absent & discrete, glandular pubescent \\
\hline B. spinosus & solitary, in the axils of leaves & reddish purple & absent & $\begin{array}{l}\text { discrete, densely glandular } \\
\text { pubescent }\end{array}$ \\
\hline \multicolumn{5}{|l|}{ Monopera } \\
\hline M. micrantha & solitary & lilac & absent & unisaccate \\
\hline M. perennis Barringer & solitary & lilac & absent & unisaccate \\
\hline \multicolumn{5}{|l|}{ Monttea } \\
\hline M. aphylla & axillary & white to lilac & absent & Discrete, densely glandular \\
\hline M. chilensis & axillary & white to lilac & absent & Discrete, densely glandular \\
\hline M. schickendantzii & axillary & white to lilac & absent & Discrete, densely glandular \\
\hline
\end{tabular}



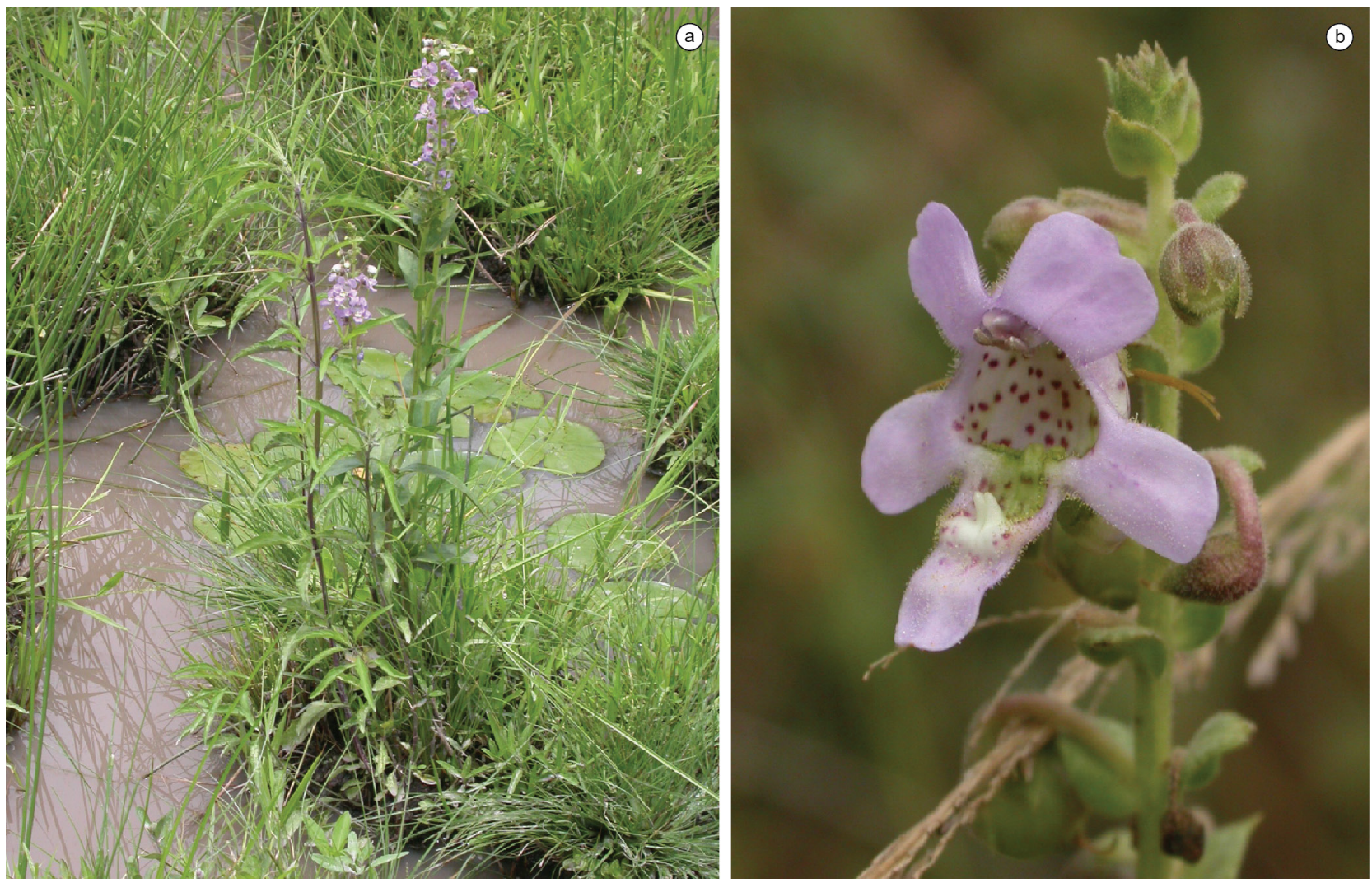

Figure 2. Angelonia salicariifolia, Porto Murtinho, Brazil: a. Habit: herbaceous plant growing in islands of humid soil among the flooded areas; b. Opened flowers show the open-mount trait, common to most species of Angelonia.
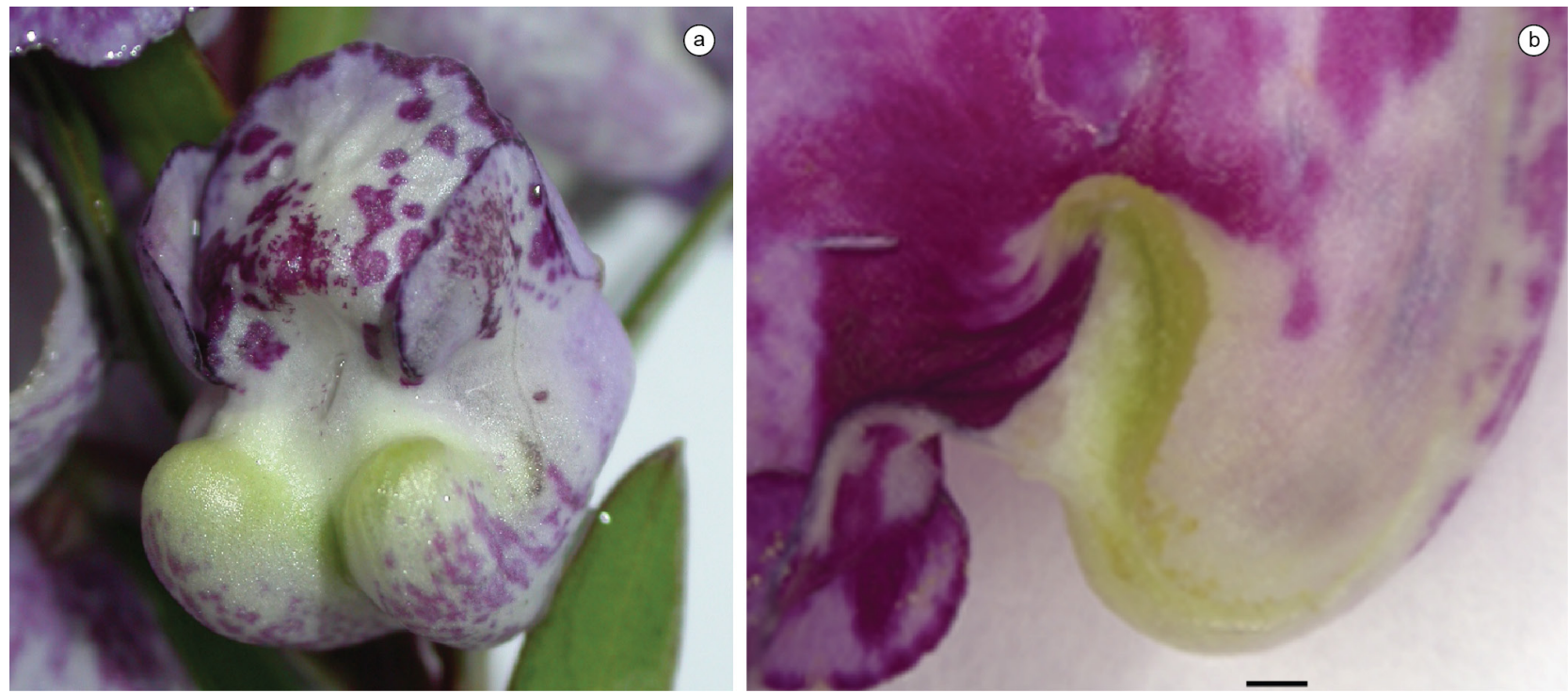

Figure 3. Oil sacs in the Angelonia integerrima flower. a. Frontal view of bud, showing the pair of oil sacs; $\mathbf{b}$. The corolla is cutted lengthwise to show the interior of the right pouch, allowing observation of the green elaiophores. (Scale $=1 \mathrm{~mm}$ ).

A. cornigera, A. goyazensis and A. eryostachis (Vogel \& Machado 1991, Machado et al. 2002, Aguiar \& Melo 2009, Martins et al. 2013).

Angelonia species have more specialized flowers in which two well-defined oil sacs are present in most of them (Figure 3a) (Table 2). The inner oil sac possesses fields of hundreds of oil trichomes forming a green carpet when observed laterally (Figure 3b) and they are separated by the ligulae (Figure 4). On the inside of the oil sacs there are a variable number of trichomes, depending on the species. In $A$. eryostachis, for example, they comprise a dense carpet in part of the sac (Figure 4). Souza \& Giulietti (2009) recognized six morphological patterns based on the Brazilian species based on leaf arrangement, inflorescence patterns, and presence of callus (or appendix) in the corolla and format of oil sacs. Notwithstanding there is no phylogenetic corroboration for this proposal of patterns between the species.

We recognized two different types of flowers in the genus Angelonia, short and long corolla tube, both requiring different 


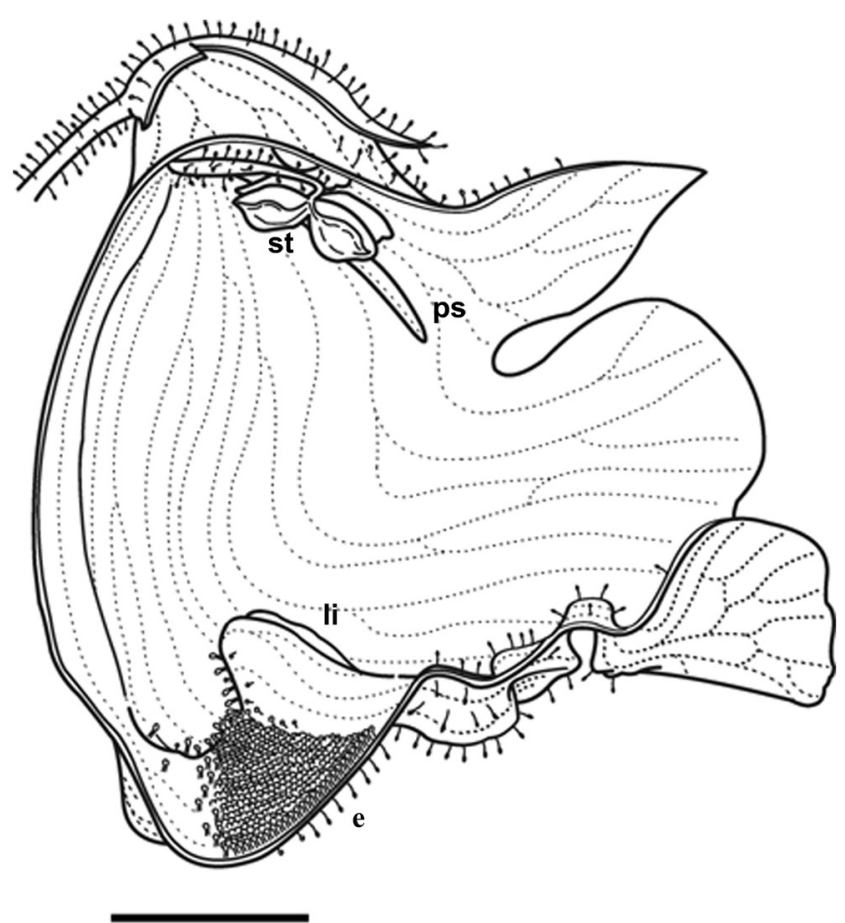

Figure 4. Lateral view of the Angelonia eriostachys flower, sectioned transversally and showing "oil sacs" and other parts of the inner corolla with trichomes. (e) elaiophores; (st) stamens; (ps) pistil; (li) ligula. $($ Scale $=2.5 \mathrm{~mm})$

modes of visiting behavior (Martins et al. 2013). In the short tubed corolla, the bees need to hold their bodies in the flowers and probably use the mandibules to do that. The short tubed Angelonia flowers also possess well-developed proximal calluses (long and bifid in most), which probably are related to force a correct position of the pollinator during visits, i.e. touching the fertile organs (Vogel \& Machado 1991, Martins et al. 2013). Moreover, some species of Angelonia have especially deep oil sacs, A. cornigera and A. pubescens, requiring long legs to access them. In $A$. cornigera a special case of adaptation by long-legged pollinators was reported (Machado et al. 2002), resembling the interactions between the Diascia oil flowers and Rediviva bees (Steiner \& Whitehead 1990). However, the relationships between deep oil sacs and long bee legs are still poorly understood for Angelonia species. Currently there is no available information on shape and size of corolla for most species in the literature, as well as a phylogenetic hypothesis, impeding a proper inference about the evolution of floral morphology.

Besides general similarities Monopera's flowers are clearly distinguished from Angelonia ones in possessing only one well developed oil sac and the lack of calluses (Barringer 1983). They are supposed to be sister-groups, despite the lack of a phylogenetic hypothesis. Indeed Monopera could represent an ancestral state of the less-specialized flowers in relation to Angelonia.

In comparison with Angelonia, the flowers of Basistemon silvaticus possess roughly defined oil sacs in which the elaiophores are widely spread, even occurring on other parts of the inner corolla (Figure 5). In addition the flowers of Basistemon do not possess ligulae and the trichomes are less dense and more widely distributed on the inner corolla (Figure 5) (Table 2). Moreover the flower entrance is larger, and the access to the elaiophores is easier for visitors (Figure 5). Based on herbarium material, Barringer (1985) observed that Basistemon species either do not present any glandular trichomes

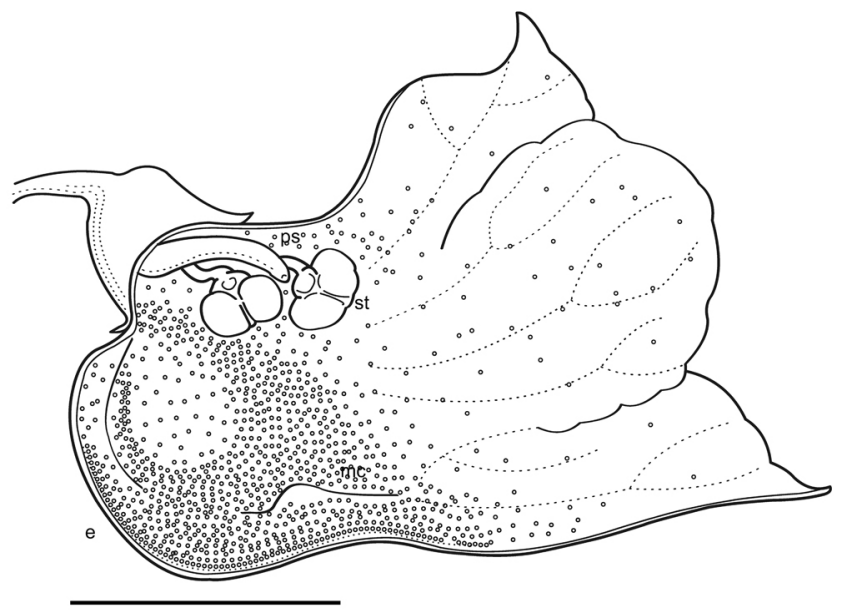

Figure 5. Lateral view of the Basistemon silvaticus flower, sectioned and showing the widely distributed elaiophores (e), stamens (st), pistil (ps) and median callus $(\mathrm{mc})$. $($ Scale $=2.5 \mathrm{~mm})$.

in the corolla (Basistemon bogotensis, B. intermedius, B. klugii and $B$. peruvianus), present trichomes only at the base of the corolla (Basistemon argutus), or present trichomes in low (Basistemon pulchellus), intermediate (Basistemon silvaticus) or high densities (B. spinosus). Nonetheless, the oil production has been confirmed only in B. spinosus (Vogel \& Cocucci 1995) and in B. silvaticus flowers (Martins et al. 2013).

Similarly to Basistemon flowers, in Monttea the oil sacs are roughly defined, but it is still recognized as bissacate, normally white or lilac and with similar size between species (Simpson et al. 1990, Sérsic \& Cocucci 1999). Monttea schickendantzii and M. chilensis have a curvature conspicuously forming two sacs, which are separated by a structure named ridge by Sérsic \& Cocucci (1999). The ridge is not observed in M. aphylla, but seems to be vestigial in Melosperma andicola (Sérsic \& Cocucci 1999). In fact this structure is probably homologous to the proximal callus of Angelonia and medium callus of Basistemon (Martins et al. 2013). Besides four didynamous stamens, the flower of Monttea also possesses a staminoid (Simpson et al. 1990). The presence of nectary was detected in all Monttea species and Melosperma as a set of cells around the base of the ovary (Simpson et al. 1990, Sérsic \& Cocucci 1999). Although in Monttea the nectar production appears only in the beginning of anthesis and in Melosperma they are not produced in collectable quantities (Sérsic \& Cocucci 1999). The trichomatic elaiophores in Monttea are densely concentrated in the sacs, but also dispersed in other parts of inner corolla, while Melosperma andicola present some glandular trichomes in the inner corolla, but no secretion was detected (Sérsic \& Cocucci 1999).

\section{Oil-Collecting Bees in Neotropical Region}

Oil-collecting behavior in bees occur in species of Melittinae and Apinae, classified in two lineages within Apidae (one family based classification of bees, see Melo \& Goncalves 2005). In Apinae the oil-collecting behavior is polyphyletic according to morphological (Roig-Alsina \& Michener 1993) and molecular phylogenies (Cardinal et al. 2010), and this behavior is present in four tribes: Centridini, Ctenoplectrini, Tapinotaspidini and Tetrapediini.

The elaiophores' morphological types, as well as their position, size and other flower characters, are related to morphological adaptations and the bees' behavior (Vogel 1974, Neff \& Simpson 1981, Buchmann 1987, Cocucci et al. 2000). The morphological features 
associated with oil gathering include combs, setae and plumose hairs on the anterior and/or middle legs, or on the sternum in females and males (Neff \& Simpson 1981, Cocucci et al. 2000, Aguiar \& Melo 2007, Taniguchi 2010). Females use floral oils to line the surface of the nest cell wall and mix it with pollen to feed larvae (Buchmann 1987, Cane et al. 1983). The males of Tetrapediini and Tapinotaspidini also collect floral oil for still unknown purposes (Vogel \& Machado 1991, Aguiar \& Melo 2009, Cappellari et al. 2011).

In the Neotropical region, oil-collecting bees are represented by the genera Centris (230 species), Epicharis (31), Tetrapedia (28) and 13 genera within Tapinotaspidini (130 species) (Moure et al. 2012, Aguiar 2007), all of these species being solitary and wood- or ground-nesting bees (Alves-dos-Santos et al. 2007). All Centris bees collect floral oils, except for some species in the subgenera Paracentris, Penthemisia and Wagenknechtia, which presumably do not collect oils (Michener 2007). Centris species collect floral oils in Calceolariaceae, Iridaceae, Krameriaceae, Malpighiaceae, Orchidaceae, Plantaginaceae and Solanaceae (Vogel 1974, Simpson et al. 1977, Cocucci 1991, Simpson et al. 1990, Vogel \& Machado 1991, Rasmussen 1999). Some species can exploit remarkably different flowers, for example Centris (Heterocentris) analis, collects floral oils in Malpighiaceae (Oliveira \& Schlindwein 2009) and in the flowers of Angelonia (Plantaginaceae) (Martins et al. 2013). Females of Centris (Paracentris) and C. (Wagenknechtia) are more strongly associated with Plantaginaceae flowers and have some modifications in their oil-collecting apparatuses (Simpson et al. 1990).

A great diversity of morphological traits associated with oil collection is characteristic of Tapinotaspidini bees (Roig-Alsina 1997, Cocucci et al. 2000). Tapinotaspidini bees forage for oil on Malpighiaceae (Teixeira \& Machado 2000), Orchidaceae (Vogel 1974, Mickeliunas et al. 2006), Iridaceae (Cocucci \& Vogel 2001), Solanaceae (Cocucci 1991), Melastomataceae (Buchmann \& Buchmann 1981), Krameriaceae (Simpson 1989), Calceolariaceae (Rasmussen 1999) and Plantaginaceae flowers (Vogel \& Machado 1991, Aguiar \& Melo 2009).

Bees of the genus Tetrapedia (Tetrapediini) collect floral oils from Plantaginaceae (Angelonia) (Vogel \& Machado 1991), Iridaceae (Sysirinchium) (Alves-dos-Santos 1999), Orchidaceae (Oncidium) (Singer \& Cocucci 1999) and Malpighiaceae (Buchmann 1987). They make illegitimate flower visits to all of these families, and do not contact the reproductive organs while gathering the oil resource. In Tetrapedia, the oil-collecting apparatus consists of a comb on the external margin of the anterior basitarsus (Neff \& Simpson 1981, Alves-dos-Santos et al. 2006).

\section{Plantaginaceae Oil-Flowers and Interaction with Oil Bees}

The flowers of Plantaginaceae species in the Angelonia clade are visited by female and/or male bees that can collect pollen, oil and/or nectar, depending on the genera. All 26 Angelonia species produce floral oils, and the oil-collecting visitors are known for ten species (Table 1). Some non-oil-collecting bees were also recorded (such as stingless bees), collecting pollen on the flowers (Martins et al. 2013). For the Basistemon species, only the visitors of $B$. spinosus and $B$. silvaticus are known and they visit the flowers to collect oil and pollen (Table 1). The only recorded oil-collecting visitor of the Monopera genus is Caenonomada bruneri (Aguiar \& Melo 2009). For Monttea, visits by some species of Centris (Paracentris) and Centris (Wagenknechtia) (Table 1) have been recorded to collect oil, besides Bombus opifex and Xylocopa sp. to collect nectar (Simpson et al. 1990, Sérsic \& Cocucci 1999). Melosperma andicola, which produces only pollen and a small quantity of nectar, has no recorded visitors (Sérsic \& Cocucci 1999).

The morphology of the flowers requires only the use of the anterior pair of legs for the collection of floral oils, and the contact with the fertile organs occurs on the head or mesoscutum (Martins et al. 2013). The pollen transfer in some Angelonia, in Monttea chilensis, M. schickendantzii, Basistemon spinosus and B. silvaticus occurs through the frons of oil-bees or mesoscutum in other Angelonia species (Vogel \& Machado 1991, Vogel \& Cocucci 1995, Sérsic \& Cocucci 1999, Martins et al. 2013). In Monttea aphylla, the ventral position of the stamens favored a sternotribic deposition of pollen (Sérsic \& Cocucci 1999).

Aside from the two well-defined "oil-sacs", the corolla of Angelonia flowers possesses the calluses, which oblige pollinators to enter the flower in the correct position (Vogel 1974, Vogel \& Machado 1991, Machado et al. 2002, Martins et al. 2013). In general the flowers of Angelonia are pollinated by bees of the genus Centris, although they are also visited by other oil-collecting bees, for example Caenonomada, Arhysoceble and Paratetrapedia (Tapinotaspidini) bees. Usually the oil-bees visiting Angelonia flowers are generalists in terms of their oil sources, visiting also other plants such as Malpighiaceae and Krameriaceae species. Centris (Xanthemisia) bicolor, for example, visits Malpighiaceae flowers, as well as Angelonia eryostachis flowers (Martins et al. 2013).

The most evident specialization among Angelonia and oilcollecting bees was observed in A. cornigera, whose pollinators, Tapinotaspis nordestina (Tapinotaspidini) and Centris hyptidis, possess a disproportionately long pair of legs which allows them to exploit the deep oil sacs of this species (Machado et al. 2002). Among the oil-collecting bees, this evidence of adaptation is remarkable, and it was also observed in the African genus Rediviva (Steiner \& Whitehead 1990). However Centris hyptidis is also able to visit other oil sources that are very distinct from Angelonia, such as Krameriaceae flowers (A.J.C. Aguiar, personal communication), which do not require elongated legs to access their oil sacs. Other species of Centris that are closely related to C. hyptidis do not possess this morphological adaptation to Angelonia flowers, despite being visitors to Angelonia as well (Martins et al. 2013). The same kind of adaptation was not observed in Caenonomada (Tapinotaspidini), another legitimate visitor of A. cornigera (Aguiar \& Melo 2009). Consequently, the evidence of strict adaptation to Angelonia observed by Machado et al. (2002) has been challenged by new evidence, and further study is required in order to understand how the co-adaptation between these partners occurred.

Flowers of Monttea (Figure 1b) produce floral oils that are collected by Centris bees of the subgenera Wagenknechtia, Paracentris and Penthemisia (Simpson et al. 1990, Sérsic \& Cocucci 1999). Monttea aphylla is visited by Centris (Penthemisia) brethesi and Centris (Wagenknechtia) vardyorum, and both species use anterior legs that possess pads of specialized setae with a high capacity for oil absorption (Simpson et al. 1990, Tadey 2011). Monttea chilensis and M. schickendantzii also are visited by Paracentris species, which also collect with the forelegs by oil absorption (Sérsic \& Cocucci 1999). In contrast with the most common four-legged pattern of oil-collecting apparatus in Centris (Neff \& Simpson 1981) the specialized visitor of Monttea and some Angelonia species have the apparatus restricted to the anterior pair of legs, where absorptive hairs replaced the oil scrapers used to grasp the epithelial elaiophors of malpighs (Simpson et al. 1990, Machado et al. 2002). Instead of being a regular source of energy, the nectaries in Monttea are suggested as a stimulator by taste to stretch the proboscis and turn the head upwards and intensify the contact with anthers (Sérsic \& 
Cocucci 1999). All oil-collecting bees registered in Monttea collect also nectar (Sérsic \& Cocucci 1999).

In northern Argentina Arhysoceble aff. huberi (Ducke, 1908) pollinates B. spinosus (Vogel \& Cocucci 1995), while in a Chaco vegetation area in Brazil Centris hyptidoides and Caenonomada spp perform this task (Martins et al., 2013.). The flower visitors of the non-oil-producing Basistemon are unknown. We assume, however, that they are pollen collectors such as Halictini and Meliponini bees, because, considering the floral morphology of these flowers, pollen is probably the only resource they offer. In Monttea (Simpson et al. 1990) and Angelonia (Vogel \& Machado 1991, Machado et al. 2002) these pollen collectors make illegitimate visits and they rarely or never act as pollinators.

The only one brief study reported interactions between $M$. perennis and Caenonomada bruneri (Tapinotaspidini), an oilcollecting bee that also visits $A$. salicariifolia (Aguiar \& Melo 2009). The characteristics of the interaction, however, in terms of the efficiency of flower visitors and the collecting behavior of the bees, remain totally unknown.

\section{Concluding Remarks}

Despite some advances over the last 20 years, knowledge of the biological aspects of oil-producing Plantaginaceae species and of interactions between these species and oil-collecting bees can still be greatly improved. Due to the rarity of most species, for many of them their basic aspects are completely unknown. Even for the bestknown genus, Angelonia, only three papers investigating ten of the almost 30 species of the group are available in the literature. Some aspects of these interactions, such as the morphological evolution of the oil sacs, the presence of calluses in the corolla and the pollination of non-oil-producing species of the Angelonia clade, should be investigated in order to clarify the evolution of mutualism between oil-bees and oil-flowers. Besides, other topics, as the chemistry of the oil-production, the role of the shifts to pollen or nectar as a reward in the reproduction of those plants is still completely unknown. It is important to mention that most species of the cited genera occur in highly endangered ecosystems in South America, and it is possible that many will become extinct without any further information being collected.

\section{Acknowledgements}

We would like to thank Antonio J. C. Aguiar, Vinicius Castro Souza and the two anonymous reviewers for their valuable comments and insights. We also give our thanks to Gabriel A. Rezende for kindly accepting our invitation to make illustrations of $A$. eryostachis and $B$. silvaticus flowers; to Gabriel A. R. de Melo and Mariana Taniguchi for allowing us to use the photographs of respectively Monopera perennis and Monthea aphylla; and to Projeto Taxonline for allowing to use their Stereo Microscopes and Automontage software. Finally, we thank FAPESP for their financial support and CNPq for the scholarship they granted to the first author.

\section{References}

AGUIAR, A.J.C. 2007. Tapinotaspidini. In Catalogue of bees in the Neotropical Region (J.S. Moure, D. Urban \& G.A.R. Melo, orgs.). Sociedade Brasileira de Entomologia, Curitiba, p.608-632.

AGUIAR, A.J.C. \& MELO, G.A.R. 2007. Taxonomic revision, phylogenetic analysis, and biogeography of the bee genus Tropidopedia Moure (Hymenoptera, Apidae, Tapinotaspidini). Zool. J. Linnean Soc. 151:511554. http://dx.doi.org/10.1111/j.1096-3642.2007.00328.x
AGUIAR, A.J.C. \& MELO, G.A.R. 2009. Notes on oil sources for the bee genus Caenonomada (Hymenoptera, Apidae, Tapinotaspidini). Rev. Bras. Entomol. 53:154-156. http://dx.doi.org/10.1590/S008556262009000100033

ALBACH, D.C., MEUDT, H.M. \& OXELMAN, B. 2005. Piecing together the "new" Plantaginaceae. Am. J. Bot. 92(2):297-315. http://dx.doi. org/10.3732/ajb.92.2.297

ALVES-DOS-SANTOS, I. 1999. Abelhas e plantas melíferas da Mata Atlântica, restingas e dunas do litoral norte do estado do Rio Grande do Sul. Rev. Bras. Entomol. 43(3-4):191-223.

ALVES-DOS-SANTOS, I. NAXARA, S.R.C. \& PATRICIO, E. F. 2006. Notes on the morphology of Tetrapedia diversipes Klug 1810 (Tetrapediini, Apidae), an oil collecting bee. Braz. J. Morphol. Scie. 23:425-430.

ALVES-DOS-SANTOS, I., GAGLIANONE, M.C. \& MACHADO, I.C. 2007. História natural das abelhas coletoras de óleo. Oecol. Bras. 11(4):544-557. http://dx.doi.org/10.4257/oeco.2007.1104.06

BARRINGER, K 1981. A revision of Angelonia (Scrophulariaceae). PhD Dissertation, University of Connecticut.

BARRINGER, K. 1983. Monopera, a new genus of Scrophulariaceae from South America. Brittonia 35(2):111-114. http://dx.doi.org/10.2307/2805946

BARRINGER, K. 1985. Revision of the genus Basistemon (Scrophulariaceae). Syst. Bot. 10:125-133. http://dx.doi.org/10.2307/2418338

BUCHMANN, S. 1987. The ecology of oil flowers and their bees. Ann. Rev. Ecol. Syst. 18:343-369. http://dx.doi.org/10.1146/annurev. es.18.110187.002015

BUCHMANN, S.L. \& BUCHMANN, M.D. 1981. Anthecology of Mouriri myrtiloides (Melastomataceae, Memecylae), an oil flower in Panama. Biotropica 13(2):7-24. http://dx.doi.org/10.2307/2388066

CANE, J.H., EICKWORT, G.C., WESLEY, F.R. \& SPIELHOLZ, J. 1983. Foraging, grooming and mate-seeking behaviors of Macropis nuda (Hymenoptera, Melittidae) and use of Lysimachia ciliata (Primulaceae) oils in larval provisions and cell linings. Am. Midland Natural. 110:257264. http://dx.doi.org/10.2307/2425267

CAPPELLARI, S.C., HARTER-MARQUES, B., AUMEIER, P., \& ENGELS, W. 2009. Mecardonia tenella (Plantaginaceae) attracts oil-, perfume-, and pollen-gathering bees in Southern Brazil. Biotropica 41(6):721-729. http://dx.doi.org/.1111/j.1744-7429.2009.00529.x

CAPPELLARI, S.C., MELO, G.A.R., AGUIAR, A.J.C. \& NEFF, J.L. 2011. Floral oil collection by male Tetrapedia bees (Hymenoptera: Apidae: Tetrapediini). Apidologie 43:39-50. http://dx.doi.org/10.1007/s13592011-0072-2

CARDINAL, S., STRAKA, J. \& DANFORTH, B.N. 2010. Comprehensive phylogeny of apid bees reveals the evolutionary origins and antiquity of cleptoparasitism. Proc. Nat. Acad. Scie. 107:16207-16211. http://dx.doi. org/10.1073/pnas.1006299107

COCUCCI, A.A. 1991. Pollination biology of Nierembergia (Solanaceae). Plant. Syst. Evol. 174:17-35. http://dx.doi.org/10.1007/BF00937691

COCUCCI, A.A., SÉRSIC, A. \& ROIG-ALSINA, A. 2000. Oil-collecting structures in Tapinotaspidini: their diversity, function and probable origin. Mitt. Munch. Ent. Ges. 90:51-74.

COCUCCI, A.A. \& VOGEL, S. 2001. Oil-producing flowers of Sisyrinchium species (Iridaceae) and their pollinators in southern South America. Flora 196:26-46.

DIVA-GIS. 2011. DIVA-GIS [Online]. Website last modified on June 17, 2011. http://diva-gis.org/ (último acesso em 08/2012).

GONÇALVES, R.B. \& MELO, G.A.R. 2005. A comunidade de abelhas (Hymenoptera, Apidae s. 1.) em uma área restrita de campo natural no Parque Estadual de Vila Velha, Paraná: diversidade, fenologia e fontes florais de alimento. Rev. Bras. Entomol. 49:557-571. http://dx.doi. org/10.1590/S0085-56262005000400017

MACHADO, I.C., VOGEL, S. \& LOPES, A.V. 2002. Pollination of Angelonia cornigera Hook. (Scrophulariaceae) by long-legged, oil collecting bees in NE Brazil. Plant Biol. 4(3):352-359. http://dx.doi. org $/ 10.1055 / \mathrm{s}-2002-32325$ 
MARTINS, A.C., AGUIAR, A.J.C. \& ALVES-DOS-SANTOS, I. 2013. Interactions between oil-collecting bees and seven species of Plantaginaceae. Flora 208(7):401-411. http://dx.doi.org/10.1016/j. flora.2013.07.001

MELO, G.A.R. \& GONCALVES, R.B. 2005. Higher-level bee classifications (Hymenoptera, Apoidea, Apidae sensu lato). Rev. Bras. Zool. 22(1):153159. http://dx.doi.org/10.1590/S0101-81752005000100017

MICHENER, C.D. 2007. The bees of the world. Johns Hopkins University Press, Baltimore, London.

MICKELIUNAS, L., PANSARIN, E. \& SAZIMA, M. 2006. Biologia floral, melitofilia e influência dos bezouros Curculionidae no sucesso reprodutivo de Grobya amherstiae (Orchidaceae: Cyrtopodiinae). Rev. Bras. Bot. 29(2):251-258. http://dx.doi.org/10.1590/S0100-84042006000200006

MOLAU, U. 1988. Schophulariaceae part I: Calceolariae. Flora Neotrop. 47:1-108.

MOURE, J.S., URBAN, D. \& MELO, G.A.R. (orgs). 2012. Catalogue of the bees (Hymenoptera, Apoidea) in the Neotropical Region - online version. http://www.moure.cria.org.br/catalogue (último acesso em 21/08/2012).

NEFF, J. \& SIMPSON, B. 1981. Oil-collecting structures in the Anthophoridae (Hymenoptera): morphology, function, and use in systematics. J. Kansas Ent. Soc. 54(1):95-123.

OLIVEIRA, R. \& SCHLINDWEIN, C. 2009. Searching for a manageable pollinator for acerola orchards: the solitary oil-collecting bee Centris analis (Hymenoptera: Apidae: Centridini). J. Econ. Entomol. 102(1):265273. http://dx.doi.org/10.1603/029.102.0136

OLSON, D.M. \& DINERSTEIN, E. 2002. The global 200: Priority ecoregions for global conservation. Ann. Missouri Bot. Gard. 89(2):199-224. http:// dx.doi.org/10.2307/3298564

OLMSTEAD, R.G., DE PAMPHILIS, C.W., WOLFE, A.D., YOUNG, N.D., ELISONS, W.J. \& REEVES, P.A. 2001. Disintegration of the Scrophulariaceae. Am. J. Bot. 88(2):348-361. http://dx.doi. org $/ 10.2307 / 2657024$

OXELMAN, B., KORNHALL, P., OLMSTEAD, R.G. \& BREMER, B. 2005. Further disintegration of Scrophulariaceae. Taxon 54(2):411-425. http:// dx.doi.org/10.2307/25065369

RASMUSSEN, C. 1999. Coevolution of the oil bee-Calceolaria system in the Andes of Peru. Dissertation, University of Aarhus.

RENNER, S.S. \& SCHAEFER, H. 2010. The evolution and loss of oiloffering flowers: new insights from dated phylogenies for angiosperms and bees. Phil. Trans. R. Soc. B 365:423-435. http://dx.doi.org/10.1098/ rstb.2009.0229

ROIG-ALSINA, A. 1997. A generic study of the bees of the tribe Tapinotaspidini, with notes on the evolution of their oil-collecting structures. Mitt. Münchner Entomol. Ges. 87:3-21.

ROIG-ALSINA, A. \& MICHENER, C.D. 1993. Studies of the phylogeny and classification of long-tongued bees (Hymenoptera: Apoidea). Univ. Kansas Sci. Bull. 55(4-5):123-173.

SÉRSIC, A. \& COCUCCI, A.A. 1999. An unusual kind of nectary in the oil flowers of Monttea: its structure and function. Flora 194:393-404.
SIMPSON, B.B. \& NEFF, J.L. 1981. Floral Rewards: Alternatives to Pollen and Nectar Author. Ann. Missouri Bot Gard 68(2):301-322. http://dx.doi. org/10.2307/2398800

SIMPSON, B.B. 1989. Krameriaceae. Flora Neot. 49:1-108.

SIMPSON, B.B., NEFF, J.L. \& SEIGLER, D. 1977. Krameria, free-fatty acids and oil-collecting bees. Nature 267:150-151. http://dx.doi. org/10.1038/267150a0

SIMPSON, B.B., NEFF, J.L. \& DIERINGER, G. 1990. The production of floral oil by Monttea (Scrophulariaceae) and the function of tarsal pads in Centris bees. Plant Syst. Evol. 173:209-222. http://dx.doi.org/10.1007/ BF00940864

SINGER, R.B. \& COCUCCI, A.A. 1999. Pollination mechanisms in four sympatric southern Brazilian Epidendroideae orchids. Lindleyana $14: 47-56$

SOUZA, V.C. \& GIULIETTI, A.M. 2009. Levantamento das espécies de Scrophulariaceae sensu lato nativas do Brasil. Pesq. Bot. 60:7-228.

STEINER. K. \& WHITEHEAD, V.B. 1990: Pollinator adaptation to oilsecreting flowers: Rediviva and Diascia. Evol. 44:1701-1707. http:// dx.doi.org/10.2307/2409348

STEVENS, P.F. 2012. Angiosperm Phylogeny Website. http://www.mobot. org/MOBOT/research/APweb/. Accessed in 8 August 2013.

TADEY, M. 2011. Reproductive biology of Monttea aphylla (Scrophulariaceae). Austral. J. Botany 59:713-718. http://dx.doi.org/10.1071/BT10282

TANIGUCHI, M. 2010. Morfologia funcional das estruturas envolvidas na coleta e transporte de óleo floral por fêmeas do gênero Centris Fabricius, 1804 (Hymenoptera, Apidae: Centridini). Dissertação de mestrado, Faculdade de Filosofia, Ciências e Letras de Ribeirão Preto, Ribeirão Preto.

TEIXEIRA, L.A.G. \& MACHADO, I.C. 2000. Sistema de polinização e reprodução em Byrsonima sericea DC (Malpighiaceae). Acta Bot. Bras. 14(3):347-357. http://dx.doi.org/10.1590/S0102-33062000000300011

VIVALLO, F. \& MELO, G.A.R. 2009. Taxonomy and geographic distribution of the species of Centris of the hyptidis group (Hymenoptera: Apidae: Centridini), with a description of a new species from Central Brazil. Zootaxa 207(5):33-44.

VOGEL, S. \& COCUCCI, A. 1995. Pollination of Basistemon (Scrophulariaceae) by oil-collcting bees in Argentina. Flora 190:353-363.

VOGEL, S. 1969. Flowers offering fatty oil instead of nectar. In Abstracts XI International Botanical Congress. Seattle, p.229.

VOGEL, S. 1974. Ölblumen und ölsammelnde bienen. Tropische subtropische Pflanzenwelt 7. Steiner, Wiesbaden, p.267.

VOGEL, S. 1986. Ölblumen und ölsammelnde bienen - Zweite Folge: Lysimachia und Macropis. Trop Subtrop Pflanzenwelt 54. Steiner, Wiesbaden, 168p.

VOGEL, S. 1990. Ölblumen und ölsammelnde bienen - Dritte Folge. Momordica, Thladianta und die Ctenoplectridae. Trop Subtrop Pflanzenwelt 73. Steiner, Wiesbaden, 186p.

VOGEL, S. \& MACHADO, I.C. 1991. Pollination of four sympatric species of Angelonia (Scrophulariaceae) by oil-collecting bees in NE Brazil Plant Syst. Evol. 178:153-178. 